\title{
K. S. Stanislavski and the physical action
}

\section{Ana Cristina LEȘE1}

\begin{abstract}
We note that the physical action in the K. Stanislavski's system expresses the same meaning as the motor action in the field of Physic Education, consisting in accomplishing a task with the help of the skeletal muscles, mainly, of the physical exercise. We sense here, the link between the Stanislavski's system and the Physical Education, link that is achieved, mainly through physical exercise. And this is how, to the question "What is the first thing in the actor's work of preparing for a role?", K. Stanislavski is in his right to assert, after a long experience of artist-researcher, that "the most appropriate and efficient procedure for preparing a role is the approach to the role with the help of physical exercise".
\end{abstract}

Key words: the physical action, theatre, sport, physical education

\section{Rezumat}

Observăm că acțiunea fizică din sistemul lui K. Stanislavski exprimă același sens ca și acțiunea motrică în domeniul educației fizice, aceasta constând în îndeplinirea unei sarcini cu ajutorul mușchilor scheletici, în principal, a exercițiilor fizice. Simțim aici legătura dintre sistemul lui Stanislavski și Educația Fizică, legătura care se realizează, în principal prin exercițiile fizice. Și astfel, la întrebarea "Care este primul lucru în pregătirea actorului pentru un rol?", K. Stanislavski are dreptul să afirme, după o lungă experiență de artist-cercetător, că "cea mai potrivită și eficientă procedură de pregătire a unui rol este abordarea rolului cu ajutorul exercițiilor fizice ".

Cuvinte cheie: acţiunea fizică, teatru, sport, educaţie fizică

\footnotetext{
${ }^{1}$ Lecturer, National University of Arts „George Enescu”, Iasi, Romania, e-mail: analese2000@yahoo.com
} 


\section{Introduction}

In this article, we seek to offer to the students who study to become actors, young actors and performance athletes a theoretical and practical knowledge framework aimed at solving the proposed goals in the field of theatre and sports. We will start from the theatrical field to the sports field. Therefore, in the forefront of this article stands K.S. Stanislavski, the founder of the Moscow Art Theatre, a reference point for the theatre of the 20th century, who was one of the innovators in theatre directing and also the most famous scientist in the art of acting. His discoveries sent to us with the title of „system" have changed the way the play can be addressed not only by actors but also by those who study it. He was a great master of theatre and theatrical thinking for two reasons: the first is for the ways trough which he solved the issue of passing the experience through the written word; the second is the practical and systematic work he has put on the border between body and soul, regardless of the use of this work in the show.

He has built a system-based program for the actor's work, based in particular on practical actions and on physical training or training of the muscle groups (through contractions and relaxations, as the author specifies), but also on the internal training, psychical and voice training. This connects with elements of the performance sport. We want to draw bridges between the two types of fields: theatre and sports, regarding the psychophysical training, in order to create a useful documentary material for teachers, students, actors and the athletes of the mentioned fields.

\section{Common elements in the theatrical and sports training}

In this chapter, we will refer to the physical aspects of the actor and the relationships that are established between the body and the soul, body and mind, which, in the theory and practice of K. Stanislavski, merge in an organic way. Thus, one of the elements common to the two fields, theatre and sports, is physical education and psychological training.

We take as a reference point the physical training, as it is concretized in two definitions: the one of general physical training and motor action, in order to make a parallel between the methods and means used by K. Stanislavski and the existing methods and means in the field of Physical Education. Another reference point that links the two fields of theatre and sport regarding the training of specialists is the psychological training or the real action, as K. Stanislavski calls it.

\section{Physical action}

From the physical action K. Stanislavski started and developed the famous "system", which is still valid in most theatre schools in the world, equalling the expression of motion action, used mainly in Theory and Methodology of Physical Education and Sport by the acknowledged theorist Gh. Cârstea, [2] who provides the following definition for motor action: "a set of motor acts (these are simple acts of behaviour performed by the action of skeletal muscles; the most representative motor acts are the physical exercises), thus structured, that he realizes a whole unit, in order to solve some immediate tasks. Motric action is a skill, with a well-established basic mechanism (walking, running, jumping, etc.)". We find that the physical action in Stanislavski's system expresses the same meaning as the motor action in the Physical Education field, consisting in carrying out a task with the action of the skeletal muscles, mainly of the physical exercises. We see here the connection of the Stanislavskian system with Physical Education, a connection that is carried out mainly through physical exercise. And here's how. To the question, „How should an actor start preparing to play a role?", K. Stanislavski is entitled to say, after a long experience as an artistresearcher, that "the most appropriate and most effective way to prepare the role is to approach that role with means of physical actions" [1].

of course, a physical action here is any manifestation of body or body segments as a whole, in order to achieve a particular process, a technique, but the author assigns to the physical action the meaning of specialized physical exercise. K. Stanislavski rightly affirmed that the analysis of the play, of the role, with a fair physical participation, creates the atmosphere of the truth of life right from the first rehearsals. By physical participation is understood a simple jump to see beyond a high fence, and through rehearsals this mean or physical exercise takes the shape, the rhythm and the attitude required by the role. Even for entering the 
scene it is required to exercise a specific body attitude of the character, but it also requires intense psychological training to master the emotions that dominate the actor, especially at the beginning of the performance. K. Stanislavski entitles the new method of working on the role the "physical action method", insisting on accepting the sense that he gave to the stage preparation, not as athletic, sporting training, focused on the intense development of physical capabilities. K. Stanislavski emphasizes that a role is created simultaneously by all faculties - intellectual, affective, soul and physical of the actor, axiomatic truth to all the theatre people.

\section{Real action}

Real action is one of the key terms of theatre in the 20th century. This real action relates to how each segment of the body brings a justification for coworking with the psychic process representative for the action to make it "real". The gesture dressed in expressiveness and affection allows the actor to create real, live action. It is known that, in order to obtain expressivity, the adjacent psychic processes occupy a priority position in the actor's training. Sport, compared to the art of theatre, holds the science of Sports Psychology, which has its roots, historians say, in Antiquity, where the interdependence between mind and body was recognized. This relationship was at the heart of the practice established by K. Stanislavski and his disciples.

One of the well-known scientists in the field of sports psychology was Coleman Griffit, an American psychologist, who first researched this field for a long time at the University of Illinois, helping coaches to improve the performance of the players. In this field, he has signed numerous research papers and articles on improving performance through psycho-logical training. In contrast to the intensification of sports psychology researches, the psycho-logical, practical training is poorly addressed in performance sports, with the exception of US sports clubs that provide highquality psychological training to high-performance sport. But by returning to world-class sports, the psychological component seems to be ignored.

We consider appropriate to address an appeal to the coaches and athletes to study and adopt elements regarding the mental preparation of the professional actor. Even though actor's Psychology does not exist as a teaching discipline, in the teaching programme for vocational theatrical education, certain psychological processes are approached at different stages of the actor's training process, with a large number of exercises that can be taken as a model in the mental training of the athlete.

\section{Simple physical action}

There are various physical actions derived from social actions, for example: to walk, to embrace, opening the window, jumping, picking up a suitcase, which, in a stage convention, represents a specific purpose. But Stanislavski refers to simple physical action, considering that at the basis of every physical action is the simple physical action. A physical action, as the definition also mentions, is a set of physical acts or simple physical actions. For example, the simple physical action chain: he approached, he raised his right hand in greeting, he handed a message, could represent a physical action, such as a meeting, executes an order or an announcement. The simple physical action is not simply an expressive movement or a gesture, it is, first of all, an action. Every action on stage is done for one purpose or another. It is called simple physical action any motion of the actor's body committed for a particular purpose. Like a dancer, a ballerina, a gymnast or a performance athlete, the actor performs simple physical actions in an organic chaining to perform a well-defined physical action. In this comparison, in which the simple physical action plays a leading role in the two areas, Theatre and Performance Sport, there is also the difference in the dosage of muscle strength and other motor skills (speed of execution, reaction speed, strength, skill) in making simple physical actions, a difference that is subject to the ultimate goal of each of the areas mentioned. Simple physical action is part of the creative process: show and competition respectively.

The simple physical action in K. Stanislavski's system is the result of the unity of movement, thought and sentiment. When performing a simple physical action on the stage, the required muscle groups and the entire nervous system contribute through will, emotions and feelings. Thus, to the 
simple physical action of the actor, as in the case of the athlete, the whole being participates. As a language, the simple physical action must be clear, easily perceived by spectators, conveying the meaning and importance of what is happening.

The role of physical action simple, and therefore, of Physical education is reflected identically in performing the two professions: actor and professional athlete, accepting that it goes self understood that these areas shall improve, adapt and distribute their objectives accordingly to the necessary simple actions.

We mention that physical training is among the tasks of Physical Education, and the psychological training will complement the field of Performance Sport. There is a tight relationship between Physical Education - Training of the Performance Athlete Preparing of the actor, the Physical Education plays an important, as a coordinator, we could say.

The simple physical action proposed by $\mathrm{K}$. Stanislavski is the concentrated expression of the psychic state of the character or of the given situation and of the physical state in which the actor is.

Adrian Dragnea states with convincingly arguments that "An individual (sportsman or actor, we add), entered into a creative activity (competition), is a man engaged with his entire biological, mental and social sphere" [3], as K.S. Stanislavski says that "the psyche can be studied only in direct connection with the actions and the deeds of the man"[4].

Exercises made up of simple physical actions useful in the training of actors and athletes

This chapter offers to student at acting, young actors and athletes with exercises taken from the famous Russian author, K. Stanislavski, exercises that we find in similar forms also in the Physical Training Methodology of Athletes. Thus, we intend to direct the actors to the sport training model and vice versa, the athletes to the theatrical psychophysical training in order to enrich their exercises program.

In K. Stanislavski's reference book, An Actor's Work on Himself, are presented only a few examples of physical exercises used in the preparation of future actors and experienced actors [4]. The exercises must be worked out daily, systematically, both at courses and at home. After describing the exercises in K. Stanislavski's system, we want to highlight similar exercises found in the Physical Education Methodology or in other materials belonging to Physical Education and Sports:

1) Lying on the back on a smooth and hard surface (for example, on the floor), while being necessary to observe the groups of muscles that clench. The attempt to relax and tighten a particular [4]:

- It is an exercise commonly used to develop force through isometric contractions;

2) Muscular relaxation for physical restoration.

3) Muscle relaxation in various attitudes: horizontal, vertical, sitting, sitting on half, standing up, kneeling, isolated, in groups, using the chair, table and other objects. In all of these positions, the muscles that contract without use must be distinguished. Contracting the muscles necessary for attitude as much as it is needed, but not those that neighbour, which must remain relaxed.

- the exercises from points 2 and 3 are found in similar variants in the VIIth part of the Physical Education lesson, part of the lesson, entitled The Recovery of the Body after Effort (decreasing the effort level), with the objectives: the gradual return of the major functions of the body and strengthening the posture reflex.

4) Muscle relaxation and exercises to maintain a correct posture.

- the Russian author does not give a concrete exercise but, as it results from the context of the fragment on page 140, he emphasizes on knowing the center of the body weight, the laws of balance and on the development of muscular groups that execute the movements dictated by the sense of balance. In another context, at one of the training lessons with the pupils it is described as an exercise for the development of a correct posture (walking with the back straight and with a book on the head), a widespread exercise among girls in the high society.

5) Raising the hand by the help of an appropriate group of shoulder muscles. The same exercise, however, with the bending of the elbow, then the hand, then the first phalange, the second, the third phalange of the fingers, and so on. Then the whole arm tends to participate in the movements of its separate parts.

- This exercise is a theme of a physical training lesson, presented in K. S. Stanislavski's manual. It 
seems very simple to describe, but its execution requires a perfect control of the muscle groups, of each muscle and of the whole body. From this fragment, it appears that no student has been able to perform this task, banal at first sight. The conclusion is that, even for the slightest physical action or movement, there is a need for preliminary training, physical and psychological.

6) The same exercise as in point 5 , but it is executed with the neck with all its twisting, both with the middle part of the back and with the feet, with the hands (also called the eyes of the body).

7) Lift the arm with the help of the shoulder muscles and strain them so that the forearm, elbow, hand, fingers and wrists to hang down and all the appropriate muscles are completely free, soft, uncluttered.

- It's also a coordinating exercise, conducted by the central nervous system, with the help of that "controller". Under conditions of un-training, the execution movements may be imprecise, inappropriate, and the sentiment can not find its precision and plasticity in its physical embodiment.

8. K. Stanislavski also remembers that in the physical training lessons about the Swedish gymnastics lesson, which contains the necessary means to straightening the external apparatus of the embodiment, as well as acrobatic exercises.

- The Swedish gymnastics system includes: exercises without sport equipment (simple, active); exercises with sport equipment (fixed ladder, bar, pommel horse, rod, crate, sticks, gym bench or string); and pedagogical gymnastics including three categories of exercises - gymnastic exercises and games.

"I need acrobatics to form the decision in you" [4].

Acrobatic exercises are considered to have a high degree of difficulty and danger, but after many exercises, it can be executed one of the following: jumping, sitting on their hands, sitting on their heads, several difficult jumping, according to the psychological analysis, that person becomes more confident in his own power. Thus, for the actor who develops his will in the field of actions and movements of the body, it will be easier to transpose (the will) in the strong moments of living in a role.
9) Dance lessons, as well as gymnastics, have a preparatory role for heavier exercises.

10) Exercises at the bar - to straighten the legs turned inside from the hips to the knees.

11) Ballet exercises for vertebral column deficiencies.

12) Bending the arms from the elbows, pulling them back and inserting a stick between the arms and the back - walking or standing. Exercise with a role in the rectification of the posture, for the straight back. 13) Exercises for the development of the facial muscles.

\section{Conclusions}

The physical action emphasized by the great Russian theater director, K. Stanislavski, in the actor's general training can be successfully used in preparing the performance athlete. Physical action is a common element of the two fields in which professional success is sought. Both the actor and the athlete, more than any other professional, must consider his body as an instrument to use for experimenting with creative ideas on the stage or in the contest space, and to aim for a complete harmony between body and mind.

In the external transposition of the role, only the necessary physical movements and actions need to be used, without further movement and energetic exhaustion, thus pointing the importance of the exercises presented above.

K. Stanislavski and other contempo-raries have developed and deepened methods of training the actors, inspired by the theories and practices of the art of movement and its benefits, as they are found in the sphere of Physical Culture.

Physical training, reaching goals such as muscle relaxation, body aesthetics, the development of motor skills (strength, resistence, skill, suppleness) is based on K. Stanislavski's method of physical action, real action, on inner living, on affective memory especially and on voice training. We have only dealt with physical action to attract the attention of sports specialists to the psycho-physical model of actors.

\section{References}

1. Abalkin N. (1955). Sistemul lui Stanislavski și teatrul sovietic, Cartea rusă, Publishing House,. 
2. Cârstea Gh. (1997). Teoria şi metodica educaţiei fizice şi sportului, National Academy of Physical Education and Sport, Bucharest

3. Dragnea A. (1996). Antrenamentul sportiv, Teorie şi metodică, Didactic and Pedagogical Publishing House, R.A., Bucharest.

4. Stanislavski K. S. (1951). Munca actorului cu sine însuşi, Însemnările zilnice ale unui elev, în româneşte de Lucia Demetrius şi Sonia Filip, Editura de Stat pentru Literatură şi Artă, Bucureşti. 